\title{
An Ethnobotanical Study of Medicinal Plants of Billawar Region, Jammu and Kashmir, India
}

\author{
Rakesh Kumar $^{1} \bullet$ Vikas Sharma $^{1} \bullet$ Sudesh Kumar $^{2 *} \cdot$ Vikrant Jaryan $^{1}$ \\ ${ }^{1}$ Department of Botany, SBBS University Jalandhar, Punjab - 144030, India \\ ${ }^{2}$ Department of Zoology Central University of Jammu $(J \& K)$ - 181143, India \\ *Corresponding Author Email id: ksudesh75@gmail.com
}

Received: 11.4.2021; Revised: 14.5.2021; Accepted: 24.5.2021

(O)Society for Himalayan Action Research and Development

\begin{abstract}
The present study was carried out in some interior regions of Billawar in Jammu and Kashmir Union Territory to collect the information of traditionally used and ethno-botanically important medicinal plants by the local communities. Proper identification of the plant species and their importance to the local people can provide useful information and play a pivotal role in efficient utilization of natural wealth. So, it is important to scientifically identify and document this natural wealth before they are lost forever. The field survey was conducted at different sites namely, Dewal, Billawar, Bhaddu, Sukrala, KotiMarhoon and Kishanpur of Kathua district from December 2019 to June 2020. During this study, a total of 64species of medicinal plants (including trees, shrubs herbs, and grasses) belonging to 40 families and 43 genera were identified and were commonly used by the local people to cure different diseases. Each recorded plant was identified for their economic importance and medicinal values for the treatment of diseases like headache, toothache, epilepsy, gastric problem,skin disorders earache, pneumonia,jaundice, etc. Therefore, the present work was an attempt to document and compute which includes the collection and compilation of different plant species of the region.
\end{abstract}

Keywords: Ethnobotany $\bullet$ Medicinal plants $\bullet$ Traditional knowledge $\bullet$ Billawar $\bullet$ Marhoon $\bullet \mathrm{J} \& \mathrm{~K}$

\section{Introduction}

Plant wealth of the Indian Himalayan region is known for its unique, natural and socio-economic values. The Himalayan region is inhabited by a large number of ethnic communities and many of them with distinct tradition, culture and life style. Within the recent past there has been a deep concern and awareness about the conservation of the fragile Himalayan ecosystem. Billawar region of Jammu and Kashmir Union Territory lies between $32.613^{\circ} \mathrm{N}, 75.604^{\circ} \mathrm{E}$ and the altitudinal elevation of $844 \mathrm{~m}$.a.s.1.People of the Billawar region have a vast knowledge of medicinal plants, where most of the inhabitants of region are living in the villages who are mostly dependent on Plant resources for medicine, fuel, food, fodder, fiber, timber and various other purposes. Due to lack of modern medical facilities, they use plants to get rid of different ailments. Earlier there was no such evidence or sufficient information either concerning the reasons for illness or concerning the plants and how they can be used as a cure. But, now in these days, the medicinal plants are used extensively for providing herbal medicine to cure several ailments (Dangwal, et.al. 2010, Kumar et.al.,2015, Rao et.al., 2015).The traditional use of plants as medicines is well known among the native communities of the area. 
The ethno-botanical account of the Himalaya reveals that many plants have been imported tothe market which in turn has resulted in the gradual loss of plants (Kumari, et.al.2012).The relationship between plants and human cultures is not limited to the use of plants for food, clothing and shelter but also includes their use for religious ceremonies ornamentation and health care (Devi, et.al. 2016). The villagers have their own remedies for medicinal treatment by using various plants or plant products present in their vicinity. Therefore, in the recent years, one can notice a global trend in the traditional system of medicines and ethno-botanical studies have become increasingly valuable in the development of healthcare system in different parts of the world. During the ancient time it was believed that the people were healthier than that of the today which is only due to their living life style and harmony with the nature(Bhatia, et.al. 2014). Documentation of such knowledge will lead to its conservation and facilitate future research on medicinal plant safety and efficacy to validate traditional use as well as prevent the destructive changes in the knowledge of medicinal plants during transmission between generations (Bunalema, et.al. 2014). The present investigation was carried out to study and document the traditional knowledge of some important medicinal plants based on the survey and discussion with local people.

\section{Materials and Methods}

\section{Study Area}

The Billawar region of district Kathua in Jammu and Kashmir Union Territory is located at $32.613^{\circ}$ $\mathrm{N}, 75.604^{\circ} \mathrm{E}$ and an elevation of 844 masl $(2,769$ $\mathrm{ft}$ ). Due to varied topography, the flora ranges from sub tropical to alpine meadows on the higher peaks.

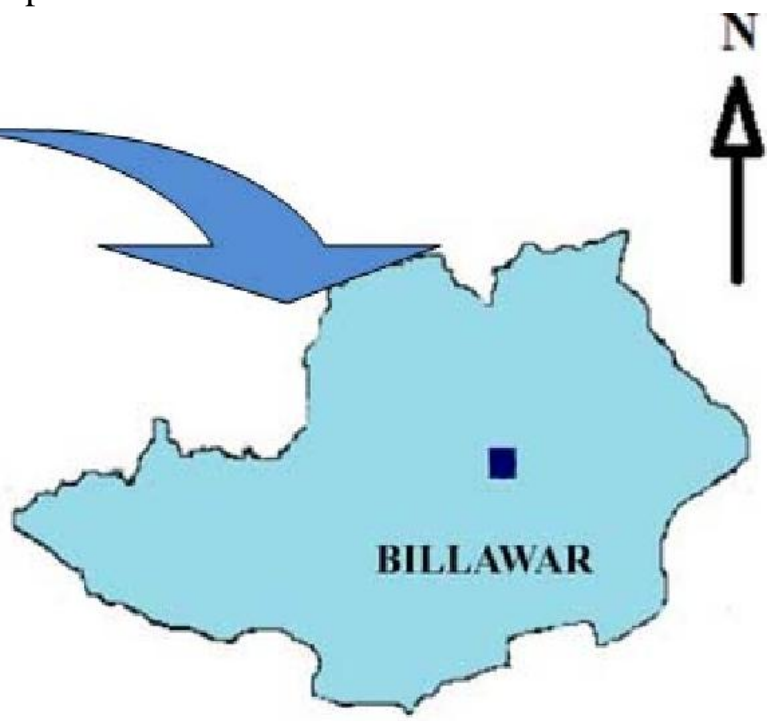

Fig 1: Map showing the location of Billawar Tehsil in Kathua District and enlarged view of Tehsil Billawar. (Source: Semanticscholar.org)

\section{Methodology}

The field study wasconducted to obtain the traditional knowledge of medicinal plants in the areas of Dewal, Billawar, Sukrala, Bhaddu, Koti,
Marhoon and Kishanpur district Kathua (J\&K) several times during the months of December 2019 to June 2020. Many elderly people were consulted from these areas. They gave us important knowledge regarding the medicinal plants and we noted their information in a 
notebook.The plants listed were searched with the help of volunteers and then the photographs of the plants were taken in their natural habitat with a digital Camera and documentation was

\section{Results and Discussion}

A total of 64 species of medicinal plants belonging to 43 genera and 40 families were identified from the region. Out of the total, 30 species were identified as trees followed by herbs 19, shrubs 11 and 4 species were identified as grasses (Table 1 and Plate 1). The family maintained. Questionnaire and personal interviews were made with old persons to collect the information on medicinal plants of the region for different diseases and purposes.

Moraceae and Poaceae were dominant among all the other families and 4 species (10\% of the total species composition) were recorded for each family (Fig. 2). The highest percentage of contribution of different ethno-medicinal plants was recorded for trees (47\%) and lowest was recorded for grasses (6\%) (Fig. 3).

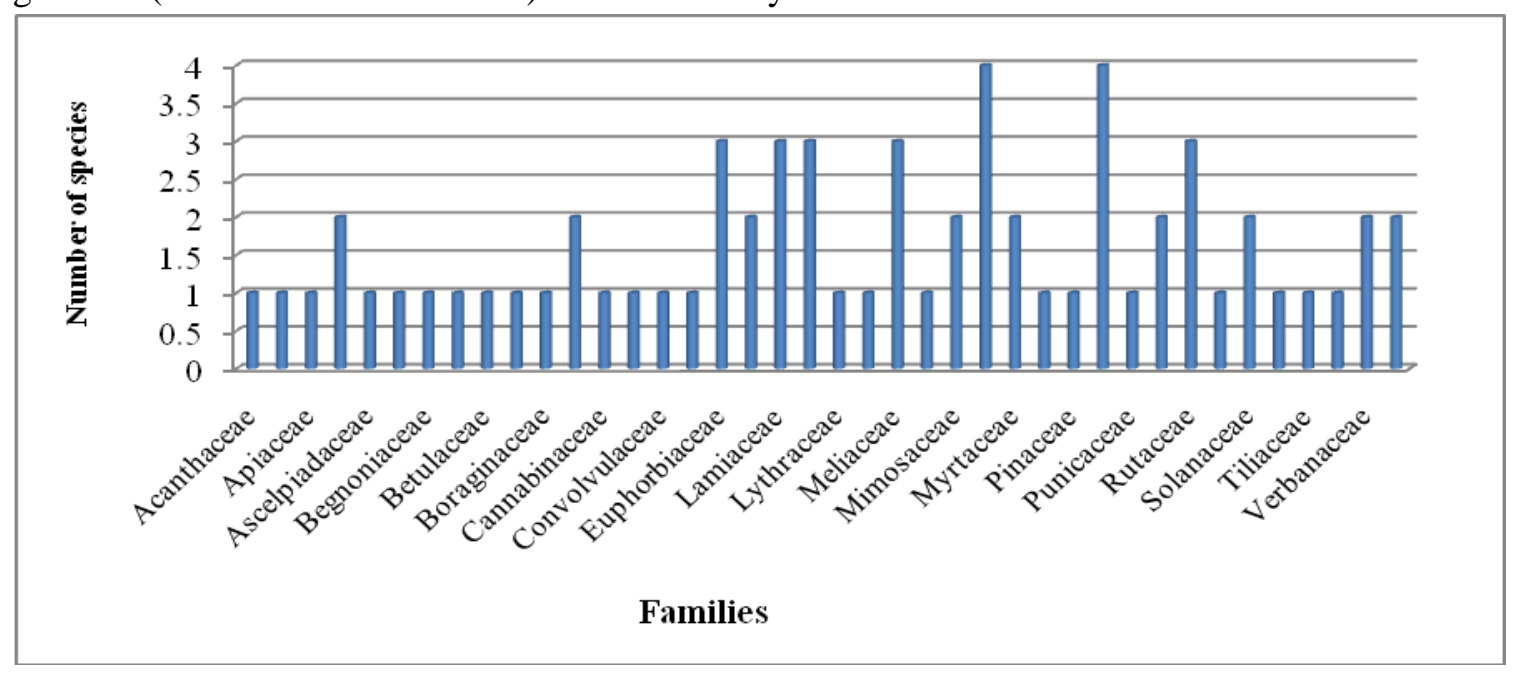

Fig. 2: Contribution of ethno-medicinal plant belonging to different families

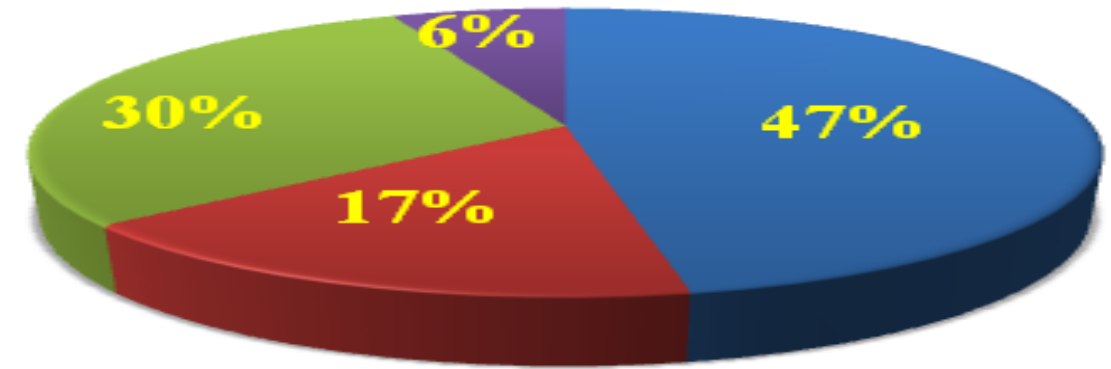

Trees $\square$ Shmubs $\square$ Herbs $\square$ Grasses

Fig. 3. Percent contribution of different ethno-medicinal plants 
The results of the study also show that different parts of the plants were used by the local communities for different traditional practices in the area. Leaves were dominated among the different parts of the medicinal plants used for various purposes by local people because more than $37 \%$ of the leave part was used for the traditional purposes (Fig. 4).

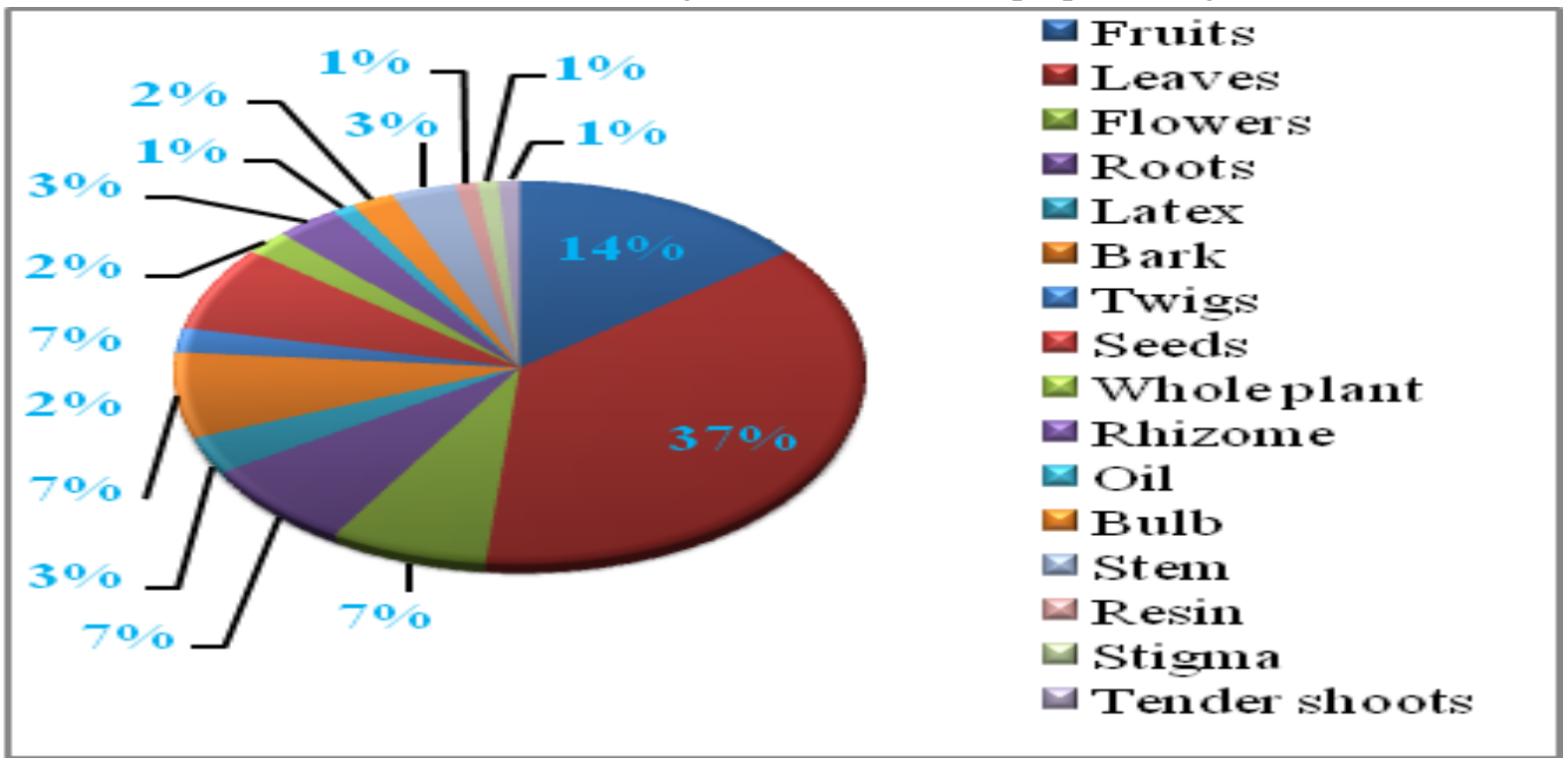

Fig. 4. Percentage of plant parts used for medicinal purposes

The medicinal plants were collected along with the documentation of significant information and records were maintained on their common names, scientific names, families and different parts of the plants used for diseases and different ailments like headache, arthritis, rheumatism, cough, cold, asthma, diarrhea, dysentery, toothache, piles, kidney stones, diabetes, jaundice, skin disorders etc. The tribal peoples i.e. Muslim, Gujar, Bakarwal, Gaddi, and Dogra Community of Billawar were consulted regarding the importance and traditional knowledge of medicinal plants because they have a great knowledge of most valuable medicinal plants in the present-day context of biological diversity conservation and its sustainable utilization(Shah, et.al.2015). It is of great value that the floral resource of Billawar region should be scientifically identified, inventorized and documented so that the local communities can gain sufficient knowledge as well as it also provides sufficient and effective information to academicians, research scholars, industrialists etc. The present study is rich in medicinal plant resources which are mostly herb species and play a vital role in treating different types of diseases. It was also investigated and observed that some species of medicinal plant are used to treat many kinds of disease; likewise, more than one plant species is used to treat a particular disease (Ganie, et.al. 2013). Ethnobotanical knowledge is very important as it reflects the practices and problems solved by the indigenous communities by their long experience. This knowledge could prove beneficial in phytopharmacological research for the discovery of new therapeutic drugs (Cordell, 2000 and Dhar, et.al.2000).). However there is continuous erosion in the traditional knowledge of many valuable plants being used for the ethno-medicines (Shah, et.al. 2009; Singh and Tyagi, 2006).). So, that the coming generations may come to know about indigenous plant species of the area. But in these 
days, anthropogenic activities such as industrialization, deforestation, habitat destruction, urbanization, illegal hunting, forest fire, invasive weeds, road construction etc. are serious threat to the species diversity of the region. Therefore, it is very necessary to document the useful ethnobotanical flora and conserve it for future generations. Hence, the steps towards the conservation of the species with appropriate measures involving the participation of the local people has been adopted in the present work. The details of ethnomedicinal plants used by the local people for different purposes are given in the (Table1).

\section{Conclusion}

The present study reveals that Billawar region is still rich in wealth of traditionally available ethnomedicinal plants. The study suggests that, the need for the integration of indigenous knowledge for sustainable development and conservation of natural resources receive more recognition and for proper scientific transformation of traditional knowledge proper ethno-botanical investigations are required. However, the study also concluded that traditional practices have dimensioned over time. Therefore, if paid attention, it may go a long way towards fostering the sustainable use of natural resources and knowledge available within the local communities. 
Table 1: List of ethnobotanically used medicinal plants of Billawar, Jammu and Kashmir

\begin{tabular}{|c|c|c|c|c|c|}
\hline S.N & Botanical Name & Local Name & Families & Plant Parts Used & Medicinal uses \\
\hline 1. & Adhatoda vasica & Brenkar & Acanthaceae & Flower and leaves & $\begin{array}{l}\text { Ash of flower and honey is used to cure whooping } \\
\text { cough and the burning leaves for asthma and cough. }\end{array}$ \\
\hline 2. & Mangifera indica Linn. & Aam & Anacardiaceae & Leaves and fruits & $\begin{array}{l}\text { Dried leaves are used for diabetes.Fruits make the } \\
\text { nervous system strong. }\end{array}$ \\
\hline 3. & Centella asiatica $L$. & Bramhi & Apiaceae & Leaves & $\begin{array}{l}\text { Dried leaves powder mix with milk are used to } \\
\text { improve mental weakness and memory. }\end{array}$ \\
\hline 4. & $\begin{array}{l}\text { Catharanthus roseus } \\
\text { Linn. }\end{array}$ & Sadabahar & Apocynaceae & $\begin{array}{l}\text { Leaves and } \\
\text { flowers }\end{array}$ & $\begin{array}{l}\text { Leaves and flower are good for diabetic patient.Leave } \\
\text { is used for wasp sting. }\end{array}$ \\
\hline 5. & Carissa opaca & Garna & Apocynaceae & Leaves, latex & $\begin{array}{l}\text { Extracts of leaves along with the leaves of Dilbergia } \\
\text { sissoo is prescribed for curing pneumonia. } \\
\text { Plant latex is applied as dressing for abscess; leaf } \\
\text { decoction is taken orally against cough. }\end{array}$ \\
\hline 6. & Calotropis procera & Desi Ak & Ascelpiadaceae & Root, leaves & $\begin{array}{l}\text { The leaves are used to cure asthma and cough. The } \\
\text { root with mustard oil is applied for the skin problems. }\end{array}$ \\
\hline 7. & Xanthium indicum & Jojra & Asteraceae & Leaves & Leaf paste is applied for alopecia affected site. \\
\hline 8. & $\begin{array}{l}\text { Oroxylum indicum } \\
\text { Linn. }\end{array}$ & Tantu & Begnoniaceae & $\begin{array}{l}\text { Stem bark, leaf, } \\
\text { and fruit }\end{array}$ & $\begin{array}{l}\text { Stem bark paste is used for the cure of scabies.Fruits } \\
\text { are used in treating cough piles and cardiac disorders. } \\
\text { Leaf decoction is used for stomachache. }\end{array}$ \\
\hline 9. & Berberis lyceum Royle & Kaemblu & Berberidaceae & $\begin{array}{l}\text { Roots, leaves, and } \\
\text { fruits }\end{array}$ & $\begin{array}{l}\text { The root extract is used to relieve kidney stones. Fruit, } \\
\text { leaves arealso applied on bleeding piles. }\end{array}$ \\
\hline 10. & Betula utilis & Bhojpatri & Betulaceae & $\begin{array}{l}\text { Twigs, bark } \\
\text { leaves, }\end{array}$ & Used for blood purifier. \\
\hline 11. & Bombax ceiba $L$. & Simbal & Bombacaceae & $\begin{array}{l}\text { Bark, fruit, and } \\
\text { root }\end{array}$ & $\begin{array}{l}\text { Root decoction is used for diarrhea. Bark is applied to } \\
\text { stop bleeding and fruit is used to treat kidney and } \\
\text { bladderulcer. }\end{array}$ \\
\hline 12. & $\begin{array}{l}\text { Cordia dichotoma } \\
\text { Linn. }\end{array}$ & Lusade & Boraginaceae & Fruits & Fruits are used against dysentery and cholera. \\
\hline 13. & Brassica campestris $L$. & Sarsoon & Brassicaceae & Seeds & $\begin{array}{l}\text { Extracted oil is used to detoxify the poisonous insect } \\
\text { or weed intake in animals. }\end{array}$ \\
\hline 14. & Brassica rapa $L$. & Gonglu & Brassicaceae & Whole plant & Whole plant is fed to cattle as galactagogue. \\
\hline 15. & Cannabis sativa Linn. & Bhang & Cannabinaceae & Leaves & Easing pain and inducing sleep. \\
\hline 16. & Carica papaya $L$. & Papita & Caricaceae & Fruit & $\begin{array}{l}\text { Ripe and unripe fruits are used for the treatment of } \\
\text { piles, and stone. }\end{array}$ \\
\hline
\end{tabular}




\begin{tabular}{|c|c|c|c|c|c|}
\hline 17. & CuscutareflexaRoxb. & Amar bel & Convolvulaceae & Whole plant & $\begin{array}{l}\text { Whole plant is used for itchy skin. } \\
\text { Seeds and stem are used for the treatment of bilious } \\
\text { disorders. }\end{array}$ \\
\hline 18. & $\begin{array}{l}\text { Cyperus rotundus } \\
\text { Linn. }\end{array}$ & Dilla & Cyperaceae & Rhizome & Roots are good antidotes for all poisons. \\
\hline 19. & Emblica officinalis & Amla & Euphorbiaceae & Fruit & $\begin{array}{l}\text { Used against Jaundice, dried fruit as good blood } \\
\text { purifier, vomiting, gastric problem. }\end{array}$ \\
\hline 20. & $\begin{array}{l}\text { Mallotus } \\
\text { philippinensis }\end{array}$ & Kaamla & Euphorbiaceae & Seeds & $\begin{array}{l}\text { The powders of seed are used for expelling out } \\
\text { intestinal worms. }\end{array}$ \\
\hline 21. & Ricinus communis $L$. & Arandi & Euphorbiaceae & Oil, leaves & $\begin{array}{l}\text { Oil is applied externally to cure itching. } \\
\text { Leaf paste is applied to the forehead to relieve } \\
\text { headache. }\end{array}$ \\
\hline 22. & Dalbergia sissoo & Taali & Fabaceae & Leaves & $\begin{array}{l}\text { The fresh juice of leaves mixed with honey dropped } \\
\text { into the eyes for improvement of eye sight. }\end{array}$ \\
\hline 23. & Mimosa pudicaLinn. & Chui-mui & Fabaceae & Leaves & $\begin{array}{l}\text { Decoction of leaves is used for diabetes.Paste of } \\
\text { leaves fasten the wound healing process. }\end{array}$ \\
\hline 24. & Mentha arvensis $L$. & Pootna & Lamiaceae & Leaves & $\begin{array}{l}\text { Leaf decoction checks flatulence, abdominal spasms } \\
\text { and act as an appetizer. }\end{array}$ \\
\hline 25. & Mentha longifolia L. & Jangalipootna & Lamiaceae & Leaves & $\begin{array}{l}\text { Leaf decoction checks flatulence, abdominal spasms } \\
\text { and act as an appetizer. }\end{array}$ \\
\hline 26. & Ocimumteluislorum & Tulsi & Lamiaceae & leaves & Used for the treatment of cure cold and cough. \\
\hline 27. & Allium cepa $L$. & Payaaz, Ganda & Liliaceae & Bulb & Juice of bulb taken orally checks nausea and vomiting. \\
\hline 28. & Allium sativum $L$. & Thom & Liliaceae & Bulb and Seeds & $\begin{array}{l}\text { Extracted oil is used as aeardrop to check otalgia. } \\
\text { Seeds are deep- fried in clarified butter are eaten to } \\
\text { cure joint pain. }\end{array}$ \\
\hline 29. & Aloe barbadensis $L$. & Kuargandal & Liliaceae & Leaves & $\begin{array}{l}\text { Skin disorders, piles and jaundice. } \\
\text { Latex is applied on forehead to get relief from } \\
\text { headache and burns. }\end{array}$ \\
\hline 30. & Woodfordiafruticosa & Dhai & Lythraceae & $\begin{array}{l}\text { Leaves and } \\
\text { Flowers }\end{array}$ & $\begin{array}{l}\text { Flowers are used for skin diseases, headache, } \\
\text { fever,Diarrhea, wounds and ulcers. The juice of } \\
\text { Leaves is used against problems associated with gall } \\
\text { bladder. }\end{array}$ \\
\hline 31. & Hibiscus rosa-sinensis & Gudaal & Malvaceae & Flowers & $\begin{array}{l}\text { Decoction of flower act as diuretic paste of flower } \\
\text { prepared in mustered oil is then applied at the site of } \\
\text { alopecia }\end{array}$ \\
\hline 32. & Toona hexandra & Tooni & Meliaceae & Leaves & $\begin{array}{l}\text { Leaves are used for chronic dysentery. } \\
\text { Flowers are used for menstrual disorders. }\end{array}$ \\
\hline
\end{tabular}




\begin{tabular}{|c|c|c|c|c|c|}
\hline 33. & Melia azedarach $L$. & Daraink & Meliaceae & Bark, leaves & $\begin{array}{l}\text { Decoction of bark is used to wash the skin against } \\
\text { achne, rashes, and dermatitis. } \\
\text { Fruit extract are taken as snake bite. }\end{array}$ \\
\hline 34. & Azadirechta indica $L$. & $\mathrm{Nim} / \mathrm{Neem}$ & Miliaceae & Leaves & Leaves eaten for curing stomach ailments. \\
\hline 35. & Acacia nilotica Linn. & Kikar & Mimosaceae & $\begin{array}{l}\text { Pods, bark, } \\
\text { flowers, gum } \\
\text { leaves and roots }\end{array}$ & $\begin{array}{l}\text { Pods are used for urinogenital disorder. } \\
\text { Gums are used for, asthma bleeding and vaginal } \\
\text { discharge. Flowers are used as tonic in diarrhea and } \\
\text { dysentery. Paste of leaves used for skin itching. Roots } \\
\text { and trunk paste used to heal wounds. }\end{array}$ \\
\hline 36. & Acacia catechuLinn. & Khair & Mimosaceae & Stem & $\begin{array}{l}\text { It is a source of Katha, which is astringent digestive } \\
\text { and useful in ailments of throat, mouth, gums, cough, } \\
\text { and diarrhea. }\end{array}$ \\
\hline 37. & Ficus religiosaLinn. & Peepal & Moraceae & $\begin{array}{l}\text { Leaves Roots and } \\
\text { fruits }\end{array}$ & $\begin{array}{l}\text { Leaves are used to treat constipation. } \\
\text { Roots are chewed to prevent gum diseases. } \\
\text { Powder of fruits is used for asthma. }\end{array}$ \\
\hline 38. & Morus alba Linn. & Toot & Moraceae & Leaves & Promote a hair growth, and stimulate appetite \\
\hline 39. & Ficus racemose Linn. & Rumbal & Moraceae & Fruits and latex & $\begin{array}{l}\text { Fruits are used for kidney diseases. } \\
\text { Latex applied externally for healing wounds. }\end{array}$ \\
\hline 40. & $\begin{array}{l}\text { Ficus } \\
\text { benghalensisLinn. }\end{array}$ & Bado & Moraceae & Latex & $\begin{array}{l}\text { Latex is used to expel out the thorns which are broken } \\
\text { down inside the body. }\end{array}$ \\
\hline 41. & Psidium guajava $L$. & Amrood & Myrtaceae & Leaves, fruit & $\begin{array}{l}\text { Chewing young leaves and cures oral ulcers.Ground } \\
\text { raw fruit is applied on forehead to relieve headache. }\end{array}$ \\
\hline 42. & Syzygiumcumini L. & Jamnoo, Tallay & Myrtaceae & $\begin{array}{l}\text { Leaves, fruit, } \\
\text { seeds }\end{array}$ & $\begin{array}{l}\text { Fruit provide relief from anorexia. Seeds and leaves } \\
\text { for diabetes,piles, and oral ulcers. }\end{array}$ \\
\hline 43. & Oxalis corniculata $L$. & $\begin{array}{l}\text { Khattibooti } \\
\text { Niki Ammi }\end{array}$ & Oxilidaceae & Whole plant & $\begin{array}{l}\text { Fresh leaves are chewed as toothache and theextract of } \\
\text { plant is used for blood purification }\end{array}$ \\
\hline 44. & Pinus roxburghiiSar. & Chir & Pinaceae & Resin & The oleo-resin is useful dressing for ulcers. \\
\hline 46. & Zea mays & Makai & Poaceae & Stigma & Corn used for kidney stone. \\
\hline 47. & Hordeum vulgare & Jau & Poaceae & Seeds & $\begin{array}{l}\text { The seeds are used to produce a special wine called } \\
\text { Shang which keep the body warmth in temperate } \\
\text { region }\end{array}$ \\
\hline 48. & Dendrocalamusstrictus & $\begin{array}{l}\text { Bamboo/ } \\
\text { Baans }\end{array}$ & Poaceae & Tender shoots, & Used as tonic and in case of calcium deficiency \\
\hline
\end{tabular}




\begin{tabular}{|c|c|c|c|c|c|}
\hline 49. & Punica granatum L. & Dadunni & Punicaceae & $\begin{array}{l}\text { Leaves, roots,Bark } \\
\text { and seeds }\end{array}$ & $\begin{array}{l}\text { The bark is used against tapeworm. The Fruit juice is } \\
\text { used for jaundice, and cough. Leaves, roots and seeds } \\
\text { are effective for anti-helminthic activity. }\end{array}$ \\
\hline 50. & Prunus persica L. & Aru & Rosaceae & Leaves & $\begin{array}{l}\text { Leaves are crushed and the paste so formed is applied } \\
\text { on cuts, wounds, for quick healing. }\end{array}$ \\
\hline 51. & Rosa indica $L$. & Gulab & Rosaceae & Flower & Used for dyspepsia, flatulence, and act as aperients. \\
\hline 52. & Xanthoxylumalatum & Tirmiru & Rutaceae & Stem & $\begin{array}{l}\text { The bark of stem is used against toothache, } \\
\text { stomachache. }\end{array}$ \\
\hline 53. & Citrus lemon Burm. & Nimbu & Rutaceae & Fruit & $\begin{array}{l}\text { Lemon juice cures haematuria. } \\
\text { Washing hair with lemon juice removes dandruff and } \\
\text { reduces hair fall. }\end{array}$ \\
\hline 54. & Citrus media L. & Gargal & Rutaceae & Fruit & Used for gastric disorders \\
\hline 55. & Populus alba L. & Safeda & Salicaceae & Bark & $\begin{array}{l}\text { Decoction of bark is antipyretic, diuretic and blood } \\
\text { purifier. }\end{array}$ \\
\hline 56. & Datura metal Linn & Datura & Solanaceae & $\begin{array}{l}\text { Leaf, twig and } \\
\text { fruits }\end{array}$ & $\begin{array}{l}\text { Twigs and Leaves are used to cure asthma.Fruit juice } \\
\text { is usedagainst falling of the hair and dandruff. }\end{array}$ \\
\hline 57. & Withania somnifera $L$. & Ashwagandha & Solanaceae & Leaves & Act as memory enhancer and also reduces obesity. \\
\hline 58. & Taxus baccata $L$. & Barmi & Taxaceae & Leaves & $\begin{array}{l}\text { Decoction of leaves is used to cure asthma, bronchitis } \\
\text { and cough. }\end{array}$ \\
\hline 59. & Grewia optiva & Dhaman & Tiliaceae & Leaves, and seeds & $\begin{array}{l}\text { Leaves and seeds are used to cure the weakness of } \\
\text { cattle. }\end{array}$ \\
\hline 60. & Celtis australis & khadak & Ulmaceae & Leaves & $\begin{array}{l}\text { Decoction of leave and fruits is used in the treatment } \\
\text { of menstrual disorders. }\end{array}$ \\
\hline 61. & Vitex negundoLinn. & Bana & Verbanaceae & $\begin{array}{l}\text { Flower and } \\
\text { leaves }\end{array}$ & $\begin{array}{l}\text { The extracts of the leaves are used to expel out worms } \\
\text { in children.Fresh flowers are extractto cure diarrhoea. }\end{array}$ \\
\hline 62. & Lantana camaraLinn. & $\begin{array}{l}\text { Panjfulli } \\
\text { (Jadi) }\end{array}$ & Verbenaceae & Leaves & $\begin{array}{l}\text { Leaves are used as an antiseptic for wounds. Leaf juice } \\
\text { used for the treatment of skin itches }\end{array}$ \\
\hline 63. & $\begin{array}{l}\text { Curcuma aromatic } \\
\text { Salisb. }\end{array}$ & Ban haldi & Zingiberaceae & Rhizome & To stop bleeding from the wounds. \\
\hline 64. & Curcuma domestica & Haldi & Zingiberaceae & Rhizome & $\begin{array}{l}\text { Powder mix with milk and given orally to quick relive } \\
\text { from cut wounds and internal bleeding disorders }\end{array}$ \\
\hline
\end{tabular}




\section{References}

Bhatia H., Sharma Y.P., Manhas R. K. and Kumar K. (2014). Ethnomedicinal plants used by the villagers of district Udhampur, J\&K, India. J. Ethnopharmocol;151 (2), Pp. 1005-1018.

Bunalema L., Obakiro S., Tabuti J.R. S. and Waako P. (2014). Knowledge on plants used traditionally in the treatment of tuberculosis in Uganda. $J$. Ethnopharmacol;151: Pp. 999-1004.

Cordell G.A. (2000). Biodiversity and drug discovery; A symbiotic relationship.

Phytochemistry; p. 463.

Dangwal L. R., Sharma A. and Rana C. S. (2010). Ethno-medicinal plants of the Garhwal Himalaya used to cure various diseases. A case study. New York Science Journal;3(12):Pp. 28-31.

Devi S., Kumar O. and Kumar M. (2016). Ethno-botanical values of anti-diabetic plants of M.P. region India. J. Medicinal Plant Studies; 4(3): Pp. 26-28.

Dhar U., Rawal R.S. and Upreti J. (2000). Setting priorities for conservation of medicinal plants: A case study in the Indian Himalaya. Biol. Cons.; p. 57.

Ganie A.H., Tali B.A. and Rather A.M.(2013). An ethno-botanical study in Budgam district of Kashmirvalley: An attempt to explore and document traditional knowledge of the area. Int. Res. J. Pharmacy; 4(1): Pp. 201-204.

Gupta A., Sahoo T. R. and Tiwari E. (2005). Ethnobotanical importance of some common aquatic and marshy plants of Sagar district. J.Bot. soc. Uni.Sagar; Pp. 65-73.

Kumar N, Wani Z A, Dhyani S (2015). Ethnobotanical Study of the Plants Used by the Local People of Gulmarg and its
Allied Areas, Jammu \& Kashmir, India Int. J Curr Res. Biosci. Plant Biol. 2 (9): 16-23

Kumari P., Joshi G.C., Tewari L.M. (2012). Indigenous uses of threatened ethnomedicinal plants used to cure different diseases by ethnic people of Almoradistrict of Western Himalaya. Int.J. Ayurvedic Herb. Med.; 2 (4), Pp. 661-678.

Rao PK, Hassan SS, Bhellum BL, Manhas RK (2015). Ethnomedicinal plants of Kathua District, J\&K India. Journal of Ethnopharmacology, 171: 12-15

Shah A., Karim A., Ahmad J. and Sharma M.P. (2015). Medicinal shrubs used by Gujjar and Bakerwaltribes against various noncommunicable diseases in Rajouri district J\&K India. Ind. J. Tradi. Knowl; 14(3): Pp. 466-474.

Shah N. H., Mahmud S. and Shamim A. A. (2009). Plants used against rheumatism by the Gujjar, Bakerwalandpahari tribes of District Poonch (J\&K).Plant Sciences; (11): Pp. 587-588.

Singh L. and Tyagi E. (2006). Plants used as toothbrushes by ethnic people of EastSikkim. Plantsciences; (2): Pp. 561562.

$$
* * * * * * *
$$

